\title{
CRIMINALIDADE FEMININA, PERFIL E PROCESSO DE RE-INSERÇÃO SOCIOESPACIAL DE EGRESSAS DO SISTEMA PENITENCIÁRIO DE PONTA GROSSA - PR
}

\author{
Women's Criminality, Profile and Process of Sociospatial \\ Re-insertion of Ex-prisioners Women in Ponta Grossa, PR
}

Msc. Karina Eugenia Fioravante
Mestrado em Gestão do Território da Universidade Estadual de Ponta Grossa - UEPG
Campus Uvaranas, Avenida General Carlos Cavalcanti, 4748, CEP: 84030-900 - Ponta Grossa (PR), Brasil

Tel: (+55 )3220-3155 - karina_frr@hotmail.com

Prof $^{\text {a }}$. Dra ${ }^{\mathrm{a}}$. Joseli Maria Silva

Mestrado em Gestão do Território da Universidade Estadual de Ponta Grossa - UEPG joseli.genero@gmail.com

\section{$a \propto \boldsymbol{Q}_{a a}$}

\begin{abstract}
Resumo
Este artigo tem por objetivo trazer algumas reflexões acerca do perfil e do processo de re-inserção socioespacial das mulheres egressas do sistema penitenciário na cidade de Ponta Grossa, Paraná. Para tanto, foram coletados dados dos arquivos do Programa Pró-Egresso, o qual tem por finalidade a prestação de assistência a pessoas saídas dos espaços carcerários. Da mesma forma, foram realizadas entrevistas com mulheres egressas com o intuito de investigar as maiores dificuldades e desafios vivenciados por elas no momento de suas re-inserção socioespacial pós-encarceramento. Para problematização dessas idéias, utilizamos o conceito de espaço, bem como as discussões acerca do conceito de gênero trazidas pelas Geografias Feministas. Concluímos que a vivência do espaço carcerário impõe determinados condicionamentos às mulheres, os quais permanecem em seus corpos e ações mesmo após sua libertação, agravando significativamente a construção de seu cotidiano. Essas mulheres são estigmatizadas pela sociedade o que aumenta suas dificuldades de re-inserção socioespacial.
\end{abstract}

Palavras-chave: Criminalidade feminina, espaço carcerário, gênero, re-inserção socioespacial.

\begin{abstract}
This article aims to bring some reflections on the profile and the process of sociospatial reinsertion of ex-prisioner's women in the city of Ponta Grossa, Parana. To this, we collected data from files of the Pro-Egresso Program, which aims to provide assistance to outputs people of prison spaces. Similarly, interviews were conducted with ex - prisioner's women in order to investigate the greatest difficulties and challenges experienced by them at the time of their's post-incarceration sociospatial re-insertion. For questioning these ideas, we use the concept of space as well as discussions about the concept of gender brought by the feminists geographies. We conclude that the experience of prison space imposes certain constraints to the women, which remains in their bodies and actions even after their release, aggravating, significantly, the construction of their daily lives. These women are stigmatized by society which increases the difficulties of their sociospatial re- insertion.
\end{abstract}

Key words: Women criminality, prision space, gender, sociospatial reinsertion

\section{Résumé}

Cet article vise à apporter quelques réflexions sur le profil et le processus de réinsertion sociospatiale des femmes de ex- prisonniers dans la ville de Ponta Grossa, Paraná. À cette fin, nous avons recueilli des données à partir de fichiers du Programme Pro-Egresso, qui vise à fournir une assistance à des personnes sorties des l'espaces de prisons. De même, on a fait des entrevues avec les ex-prisionniers des femmes afin d'enquêter sur les plus grandes difficultés et des défis vécus par eux au moment de la réinsertion sociospatiales après l'incarcération. En interrogeant ces idées, nous utilisons la notion d'espace ainsi que des discussions sur le concept de genre provoquée par la géographie féministe. Nous concluons que l'expérience de l'espace carcéral impose certaines contraintes sur les femmes, qui demeurent dans leur corps et les actions, même après sa libération, de façon significative aggravant la construction de leur vie quotidienne. Ces femmes sont stigmatisées par la société ce que augmente les difficultés de la réinsertion sociospatiale.

Mots clés: Criminalité des femmes, espace de prison, genre, réinsertion sociospatiale.

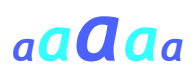

Revista da ANPEGE, v. 7, n. 7, p. 61-82, jan./jul. 2011.

ISSN 1679-768 X @ 2003, Associação Nacional de Pesquisa e Pós-Graduação em Geografia. Todos os direitos reservados. 


\section{INTRODUÇÃO}

Quando observamos a história do desenvolvimento da Geografia científica percebemos que certas temáticas, e até mesmo, determinados sujeitos vêm sendo negligenciados, bem como suas espacialidades ignoradas. Discursos periféricos e corporalidades diferenciadas vêm sendo esquecidos, limitando dessa forma o escopo de interesses da Geografia brasileira a determinadas temáticas que, se já não estão esgotadas, vêm se extenuando a cada nova "publicação". Sendo assim, este artigo, o qual tem por objetivo discutir o perfil e o processo de re-inserção socioespacial de mulheres egressas do sistema penitenciário na cidade de Ponta Grossa, Paraná, se apresenta enquanto um desafio e uma tentativa de ampliar as discussões acerca da temática de gênero na Geografia Brasileira, e da mesma forma, objetivamos evidenciar o quanto as discussões das perspectivas feministas da Geografia podem ser um interessante viés analítico.

A criminalidade feminina é um fenômeno em ascensão no Brasil, sendo facilmente perceptível a partir do aumento expressivo do número de mulheres encarceradas nos últimos vinte anos. De acordo com dados do Departamento Penitenciário Nacional (DEPEN), até dezembro de 2010, estavam presas em regime fechado no Brasil 176.910 pessoas, sendo que deste total, apenas 7\% são mulheres. Em quase dez anos, a população encarcerada feminina cresceu mais de $300 \%$. No ano de 2000, eram 3.240 mulheres presas e no ano de 2009, o número saltou para 10.171. Ainda de acordo com o DEPEN, a população encarcerada feminina no Brasil cresceu mais de $37 \%$ nos últimos quatro anos, um crescimento anual de mais de $11 \%$. Os estados que apresentam uma população encarcerada mais expressiva, são, São Paulo, Rio Grande do Sul, Minas Gerais e Rio de Janeiro. No estado do Paraná, estão encarceradas 7.750 pessoas. Deste total, apenas 321 são mulheres, as quais estão internadas em estabelecimentos exclusivamente femininos ou mistos.

Não é difícil de concluir que a população feminina nas penitenciárias, presídios e cadeias no Brasil é muito menor que a masculina. Entretanto, no caso feminino, observamos um percentual de crescimento muito maior quando comparado ao caso masculino. Na cidade de Ponta Grossa, assim como no restante do país, essa tendência também é observada na medida em que notamos um crescente número de mulheres que saem do sistema penitenciário todo o ano.

Em trabalho de campo realizado nos arquivos do Programa Pró-Egresso na cidade de Ponta Grossa, o qual tem por objetivo prestar auxílio às pessoas que saem dos espaços carcerários e as que cumprem penas restritivas de direito, observamos que seguindo a tendência nacional, na cidade de Ponta Grossa, também houve um aumento expressivo no número de mulheres que tiveram algum problema com o sistema legal. No ano de 2000 foram verificados apenas 18 casos de mulheres em conflito com a lei, já em 2007, esse número aumentou para 113, ou seja, um crescimento de $527 \%$.

Nosso texto se constrói da seguinte forma, primeiramente trazemos algumas discussões sobre a criminalidade feminina, apontando que esta deve ser compreendida de forma diferente da masculina. Utilizamos como aporte às nossas reflexões teóricas o conceito de gênero, elemento trazido pelas correntes feministas da Geografia. A partir de uma reflexão a partir do espaço carcerário, problematizado a partir de uma perspectiva especificamente geográfica, analisamos o quanto a vivência dessa espacialidade interfere no processo de re-inserção socioespacial das mulheres egressas, condicionando seus corpos, ações e percepções mesmo após a libertação. Finalizamos nossa reflexão, discutindo acerca de seu perfil, o qual engloba questões como maternagem, afastamento sentimental da família, tipificação de seus delitos, elementos que de forma direta ou indireta, interfere no seu cotidiano pós-cárcere.

\section{SOBRE ESPAÇO, CRIMINALIDADE FEMININA E GÊNERO: UMA ABORDAGEM GEOGRÁFICA}

Inicialmente, observamos que alguns questionamentos se mostram extremamente relevantes para melhor apreensão da temática contida neste artigo; como a Geografia pode problematizar a 
questão da criminalidade feminina? Existe uma maneira, especificamente geográfica, para isso? Como as ideias trazidas pelas perspectivas feministas podem contribuir para melhor apreensão desse fenômeno? São essas as perguntas que buscamos responder nesse artigo, e já de antemão acrescentamos que esse fenômeno possui um elemento essencial, o qual nos autoriza a discuti-lo: o espaço. Ou seja, adotamos em nossa reflexão a postura de que, nós, geógrafas (os), podemos direcionar nosso olhar investigativo para uma infinita gama de fenômenos, desde que o espaço, ou se podemos colocar dessa forma, a espacialidade, se apresente enquanto elemento central em nossa reflexão (GOMES, 2009).

O espaço é um conceito chave na ciência geográfica, compreendido como uma dimensão da sociedade, sendo diversamente concebido em diferentes perspectivas teóricas e metodológicas. Corrêa (1995) alerta que o conceito de espaço teve várias abordagens ao longo da história da ciência geográfica, sendo valorizado e desprezado de acordo com o contexto científico vigente. Entendido enquanto matriz, simbólico, campo de forças para lutas de classes, fragmentado, articulado, dinâmico, as abordagens sobre o espaço sempre foram plurais.

Utilizamos em nossa reflexão a abordagem sobre o conceito de espaço proposta por Massey (1999) Segundo a autora existem três proposições a partir das quais podemos adquirir uma visão diferenciada acerca desse conceito. Para ela, o espaço é produto de inter-relações, uma esfera que possibilita a coexistência da multiplicada, sempre em permanente processo de construção. Nas palavras da geógrafa,

Primeiro, reconhecemos o espaço como o produto de inter-relações, como sendo constituído através de interações desde a imensidão do global até o intimamente pequeno. (Esta é uma proposição que não surpreenderá a todos os que têm lido a recente literatura anglófona.) Segundo, compreendemos o espaço como a esfera da possibilidade da existência da multiplicidade, no sentido da pluralidade contemporânea, como a esfera na qual distintas trajetórias coexistem; como a esfera, portanto, da coexistência da heterogeneidade. Sem espaço, não há multiplicidade; sem multiplicidade, não há espaço. Se o espaço é, sem dúvida, o produto de inter-relações, então deve estar baseado na existência da pluralidade. Multiplicidade e espaço são co-constitutivos. Terceiro, reconhecemos o espaço como estando sempre em construção. Precisamente porque o espaço, nesta interpretação, é um produto de relações - entre, relações que estão, necessariamente, embutidas em práticas materiais que devem ser efetivadas, ele está sempre no processo de fazer-se. Jamais está acabado, nunca fechado. (MASSEY, 2008, pg. 29)

A autora também defende a idéia de que o espaço não pode ser visto como algo fechado, completo, pronto, e sim, como sempre em construção. A partir dessas proposições a autora pretende reforçar o quanto o espaço apresenta um caráter ativo, influenciando e condicionando práticas e comportamentos de sujeitos, sendo da mesma forma, construído e remodelado a partir destes. Da mesma forma, como nos trouxe Santos (2008), todas as relações sociais são espaciais, e, portanto, devem sem compreendidas a partir de sua espacialidade. A questão da criminalidade feminina deve ser apreendida da mesma forma. Cada vez mais, as/os geógrafas/os vêm se empenhando em demonstrar que essas relações socioespaciais também são permeadas por especificidades, tais qual gênero, raça, sexualidades, etnia, entre outros. É isso que levamos em conta em nossa reflexão.

Com as discussões feministas na Geografia surgem novas possibilidades metolodológicas e conceituais, bem como novas temáticas, até então invisíveis. É interessante afirmar que a abordagem feminista é plural e há múltiplas abordagens sobre ela. Para a maioria dos pesquisadores engajados com essa área, a Geografia Feminista é vista como uma possibilidade de expansão para abordagens mais amplas e alternativas. (OBERHAUSEN et. al. 2003). Já prosperamente desenvolvida em países anglo-saxões desde a década de 1970 , a abordagem feminista ainda é pouco expressiva no Brasil. $\mathrm{O}$ conceito de gênero já fortemente incorporado pelas geógrafas feministas, principalmente norte americanas e inglesas, ainda sofre resistência na Geografia brasileira. 
Quando analisamos a criminalidade feminina utilizando o conceito de gênero como elemento metodológico, temos uma perspectiva crítica capaz de dar inteligibilidade à aceitação desse fenômeno por parte da população. A identidade feminina está sobrecarregada de estereótipos construídos culturalmente, os quais constrangem a sociedade a esperar certas atitudes e determinados papéis pré-estabelecidos quanto ao 'ser mulher'. Da mulher se esperam a passividade, a gentileza e a docilidade, 'qualidades' estas nem sempre acentuadas e facilmente perceptíveis nas mulheres envolvidas no ambiente criminal e mesmo nas reclusas em penitenciárias e cadeias. Silva (2007) discutindo os papéis de gênero que condicionou os corpos em nossa sociedade, afirma que,

O padrão hegemônico que categorizou os corpos, também lhes atribuiu papéis sociais a serem desenvolvidos e, mais do que isso, instituiu uma forte carga naturalista no seu desempenho. Aos sujeitos femininos se atribui o desempenho da maternagem, passividade, docilidade, fragilidade e emoção. Ao sujeito masculino, a agilidade, força, agressividade, astúcia e raciocínio. (SILVA, 2007, p.102)

O conceito de gênero aparece assim, como importante ferramenta conceitual, metodológica e também política, proporcionando uma nova leitura da realidade socioespacial. Silva (2003) discute que a utilização do conceito de gênero como ferramenta explicativa confere uma análise mais complexa e profunda do espaço geográfico, pois traz elementos ignorados pela Geografia Tradicional brasileira, como o papel da mulher na produção do espaço, por exemplo.

Para esse artigo utilizamos as idéias de Silva (2005) acerca da potencialidade do conceito de gênero para a ciência geográfica. A autora discute que o conceito de gênero traz consigo valiosos elementos de pluralidade e multidimensionalidades, englobando aspectos esquecidos pela ciência geográfica tradicionalista. Entendemos o conceito de gênero enquanto uma representação, e sendo assim, diferenciado temporal e espacialmente

Silva (2004) discute a utilidade desse conceito como ferramenta explicativa para muitos fenômenos, os quais não são respondidos de forma satisfatória por outras correntes do pensamento geográfico. De acordo com a mesma autora, pode-se concluir que o uso do conceito de gênero permite uma análise mais complexa e profunda do espaço geográfico, uma vez que são levados em considerações elementos geralmente postos de lado pela geografia tradicional, como por exemplo, o papel da mulher na produção do espaço. Com relação a isso, McDowell (1999) traz uma discussão crítica à dominação masculina e atribui a pequena visibilidade da mulher na produção do espaço devido ao forte apego da ciência geográfica a agentes hegemônicos.

Neste artigo evidencia-se, como já afirmamos anteriormente, o conceito de gênero enquanto representação, logo, construção social diferenciada espacialmente. (SILVA, 2007). Ou seja, cada sujeita/o ou grupo social em diferentes espaços sociais e temporalidades, está constantemente re construindo e re - significando as representações de gênero.

Como nos aponta Butler (2003, p. 20) a categoria mulher é genérica e nega as especificidades que envolvem a complexidade da existência humana. Segundo ela, as mulheres não formam um conjunto unitário, pois "se alguém é uma mulher, certamente não é tudo que esse alguém é". A filósofa considera impossível separar o conceito de gênero do processo de formação da identidade feminina, e também alerta para as interseções estabelecidas entre gênero e as especificidades, tais quais, raça, classe social, etnia, opção sexual, entre outras. Nesse sentido, gostaríamos de acrescentar as reflexões da autora, apontando que, a essas especificidades, podemos acrescentar também algumas práticas espaciais, como é o caso das mulheres envolvidas com ambientes criminais.

Como nos lembra Rose (1993) não são as diferenças biológicas que colocam certos corpos em uma posição de poder, mas sim, as diferenciações culturais e simbólicas que a sociedade faz desses mesmos corpos. O conceito de gênero, permanentemente re - elaborado e re-significado, nos permite compreender que existe uma representação social do que é ser "homem" ou ser "mulher", representação esta que é consolidada nos gestos e ações simples e quotidianas. Esta identidade de gênero, construída culturalmente, pode não ser compatível com as vivências do sujeito, surgindo assim, disparidades. 
O que a maioria dessas/es pesquisadoras/es vem objetivando alertar é o quanto o espaço tem papel central na construção dessas representações de gênero, reconfigurando e desconstruindo em diversas situações seus estereótipos e performances. Em nossa reflexão essa idéia é central, uma vez que as mulheres envolvidas com práticas criminosas não correspondem, ou colocando de outra forma, não apresentam características condizentes com as normatizações de gênero.

É interessante alertar para o fato de que os espaços são vivenciados e construídos de formas antagônicas por diferentes sujeitos, e indo mais além, é imprescindível compreender que a vivência de determinados espaços interfere ativamente na forma como determinados sujeitos são "lidos" socialmente. Os sujeitos participantes do mundo criminal, encarcerados e egressos do sistema penitenciário são exemplos disso. Esses indivíduos tendem a ser estigmatizados pela sociedade devido as suas vivências espaciais, não sendo rara a utilização de termos pejorativos para qualificá-los. No caso feminino, as representações normativas de gênero são fator de peso ainda maior nessa dinâmica, uma vez que seu comportamento espacial não condizente provoca constrangimentos ainda maiores.

Badinter (2005) discute a criminalidade feminina e a dificuldade que a sociedade e, mesmo pesquisadoras/es feministas, encontram frente à temática. Possivelmente por colocar em dúvida a premissa de que as mulheres são seres frágeis e indefesos, pesquisar aspectos como este seja tão difícil para algumas/uns pesquisadoras/es feministas. A autora discute de forma honesta a violência cometida por mulheres e nos lança o desafio de por ao lado a segurança que a vitimização confere às mulheres e encarar esse fenômeno com maturidade, questionando se a violência feminina é uma resposta a dominação masculina, ou se ela simplesmente pode ser genuína.

Para a autora tanto nos períodos de extrema violência, como genocídios e massacres, quanto no cotidiano, às mulheres podem, sim, tornarem-se violentas, ou seja, matam por interesses próprios ou sadismo. Sendo assim, a tentativa de explicar a violência feminina trazendo à culpa a dominação masculina é uma forma falha e pouco, ou nada, contribui para a 'libertação' das mulheres. Muito pelo contrário, apenas perpetua a visão indefesa e angelical das mulheres, visão esta que vem sendo utilizada há muito tempo como justificativa para a 'demonização' da sexualidade masculina. A autora conclui que,

Ao querer ignorar sistematicamente a violência e o poder das mulheres, ao proclamá-las constantemente oprimidas e, portanto, inocentes, traça-se em negativo o retrato de uma humanidade cindida em dois e pouco conforme à verdade. De um lado, as vítimas da opressão masculina, do outro, os carrascos onipotentes. Para lutar contra essa situação, vozes feministas cada vez mais numerosas investem contra a sexualidade masculina, apontada como a raiz do problema. Ao fazê-lo, elas delineiam os contornos de uma sexualidade feminina em contradição com a evolução dos costumes e redefinem uma 'natureza feminina' que acreditávamos esquecida. (BADINTER, 2005, p. 92)

Como discutem Soares e Ilgenfritz (2002, pg. 64) a bibliografia que se relaciona, especificamente, as discussões acerca da criminalidade feminina são escassas e apontamos que mais raros ainda são os trabalhos com caráter essencialmente geográfico que abordam essa temática. As autoras afirmam que podemos acrescentar a esse problema, um outro empecilho, ou seja, o fato de alguns pesquisadores ainda defenderem determinadas teorias explicativas ultrapassadas, as quais são sustentadas por elementos que pouco, ou nada contribuem para o real desenvolvimento e aprimoramento da problemática. Em suas palavras,

A base das explicações biopsicológicas dos pensadores da virada do século XX residia na noção de uma influência dos 'estados fisiológicos' pelos quais a mulher passaria nas fases da puberdade, da menstruação, da menopausa, do parto (estado puerperal) - períodos em que estaria mais propensa à prática de crimes. Durante a vigência desses fenômenos biológicos que atingem o corpo da mulher, o seu estado psicológico ficaria alterado pela irritabilidade, instabilidade e agressividade. Por isso ela estaria mais facilmente sujeita à prática de delitos (cujas vítimas típicas seriam as crianças) como o aborto, o infanticídio, o abandono de incapaz etc., ligados à sua condição de mulher e sua associação natural à maternidade. (SOARES e ILGENFRITZ, 2002, p. 64) 
Obviamente, é necessário também se levar em conta possíveis fatores biológicos e psicológicos a fim de se compreender o fenômeno da criminalidade feminina de forma mais ampla. Mas, considerar esses fatores como satisfatoriamente explicatórios é no mínimo, ingenuidade. Concordamos com Gelsthorpe (2002) quando a autora discute que a criminalidade feminina tem sido vista ao longo da história como uma anomalia social. Sendo assim, é impossível a utilização das mesmas metodologias que explicam o comportamento criminal masculino.

Podemos afirmar que tanto a criminologia quanto o feminismo construíram narrativas explicativas que justificam a subordinação das mulheres, seja enquanto vítimas ou autoras de atos criminosos. Com as críticas pós-estruturalistas trazidas por intelectuais como Butler (2003 e 2004), bem como, com as proposições pós-modernas discutidas por Harvey (1993) e Lyotard (1994) é difícil a defesa de uma metanarrativa que possa falar em nome das 'mulheres'. A desconstrução do gênero enquanto uma categoria unitária e homogênea, ou seja, sua abertura para diversas possibilidades representacionais parece um viés importante que as teorias criminológicas deveriam abraçar, no sentido de problematizar a criminalidade feminina de forma adequada, deixando de lado explicações vagas e que pouco dão conta de explicar esse fenômeno atualmente.

É muito interessante que, comumente, associa-se às mulheres crimes que estão intimamente ligados à espacialidade doméstica e maternal, ou seja, o aborto e o infanticídio. Soares (2006) discute que historicamente a identidade feminina tem sido associada à esfera privada. Na mesma proporção, a esfera pública, ou seja, o espaço do político e do conhecimento era resguardado aos homens. A autora discute que na medida em que a vida privada da mulher começou a se tornar cada vez mais politizada, houve a migração das mulheres também para os espaços públicos, tornando assim visíveis aspectos de sua vivência que até então eram ignorados. Lembramos nesse momento das proposições de Habermas (1984) e Arendt (1983) quando os autores afirmam que a esfera pública é o local, por excelência onde os sujeitos ganham, ou deveriam ganhar, visibilidade e voz.

Nas idéias de Soares (2006) ocorre um redimensionamento dos papéis femininos na sociedade, ou seja, a mulher passa a viver espacialidades até então exclusivamente masculinas, como o mercado de trabalho, por exemplo. É interessante atentar para o fato de que esse processo ainda está em construção. Torna-se, assim, importante desconstruir a falsa imagem de que a casa e a vida familiar são as únicas espacialidades de existência cotidiana de mulheres. Nessa perspectiva, Soares (2006) lembra que o preconceito e a desigualdade de gênero ainda permanecem especialmente no sentido das mulheres terem menos condições de inserção no mercado de trabalho, conseguindo assim, geralmente cargos subalternos e com baixa remuneração, ou em situações extremas, em atividades irregulares e ilegais. A autora conclui,

Não queremos dizer com isso que a motivação das mulheres para praticar um crime se encerre apenas nas privações socioeconômicas, nem vincular mecanicamente a pobreza à violência. $\mathrm{O}$ que queremos é chamar a atenção para o maior grau de vulnerabilidade das mulheres pobres, sua exposição maior ao atrativo de ganho fácil exercido pelo mundo do crime. Nesse sentido, pesariam tanto a necessidade da mulher em prover seu próprio sustento como sua crescente responsabilidade na manutenção da família, fazendo com que a busca por alguma forma de rendimento se torna premente. Com a necessidade de se garantir o presente, limitam-se as expectativas para o futuro e prioriza-se o imediato - o que pode facilitar, sobretudo no caso das mais pobres e desamparadas, o envolvimento em atividades criminosas e lucrativas a curto prazo. (SOARES, 2006, p. 13)

Em uma linha de pensamento semelhante, Lemgruber (1999) traz uma interessante discussão sobre a pequena participação da mulher no ambiente criminal, mesmo após a mulher já ter conquistado seu papel nos mais diversos setores sociais, e constata que, apesar da maior participação feminina em outros setores da vida pública, como o mercado de trabalho, o número de mulheres encarceradas se manteve constante, não aumentando proporcionalmente a sua maior participação na vida pública. 
Entretanto, para Souza (2006), embora grandes avanços, as mulheres ainda não conseguiram romper totalmente a desigualdade social, econômica e cultural que sempre estiveram presentes nas relações de gênero no Brasil. Bastos (1997, p. 57) apresenta uma perspectiva similar e afirma que a pequena importância e também discussão acerca da criminalidade feminina acontece devido ao "forte preconceito que atribui pouco ou nenhum valor às manifestações de desajuste social da mulher".

A expressão da criminalidade feminina na sociedade brasileira vem aumentando gradativamente, mediante a incorporação de novas práticas e táticas ilegais, um indicativo disso é o aumento do número de mulheres encarceradas, fenômeno que vem ocorrendo no Brasil de forma geral. $\mathrm{O}$ gráfico a seguir demonstra e evolução do número de mulheres encarceradas no país ao longo da última década.

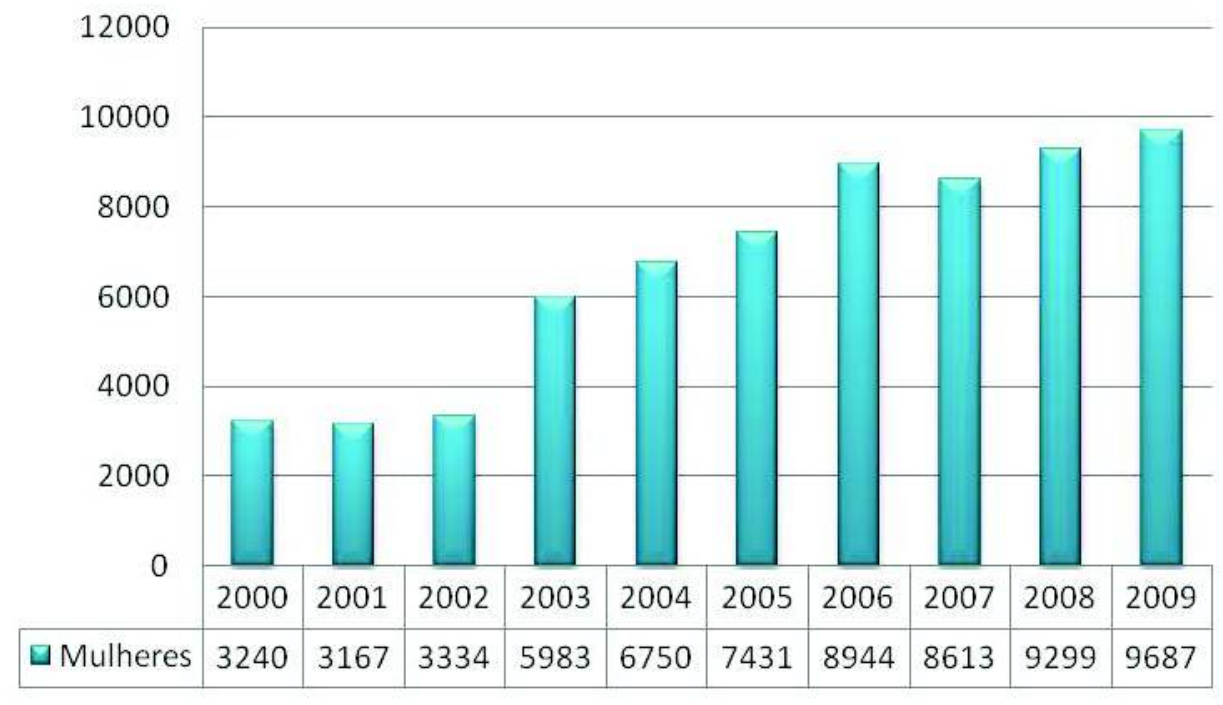

Figura 1 - Gráfico da Evolução do número de mulheres encarceradas no Brasil durante os anos de 2000 a 2009 Fonte: Departamento Penitenciário Nacional

Organização: FIORAVANTE, K.E. 2010

Utilizamos para construção desse gráfico os dados disponibilizados pelo Departamento Penitenciário Nacional (DEPEN), o qual vem publicando, anualmente em sua página virtual, dados referentes à população encarcerada no Brasil, sempre indicando o quanto o número de encarcerados vem crescendo em nosso país. Com base no gráfico, podemos apontar um aumento do número de mulheres em situação de prisão de aproximadamente $300 \%$ em menos de uma década. É válido comentar que, quando comparamos esses dados com os relacionados à população masculina, concluímos facilmente que as mulheres ainda representam uma porção ínfima da população encarcerada total. Entretanto, quando analisamos o percentual de crescimento de forma conjunta, observamos que, mesmo sendo menos representativa, a população encarcerada feminina apresenta um maior percentual de crescimento.

Apesar do crescimento expressivo do número de sujeitos encarcerados, suas vivências cotidianas ainda permanecem enquanto temática pouco explorada pela Geografia. O espaço carcerário apresenta-se enquanto um rico viés analítico para nós, geógrafas/os, uma vez que é construído a partir das mais diversas práticas, possibilitando dessa forma, reflexões variadas, inéditas, ousadas realizadas mediante a utilização de inúmeras metodologias analíticas. Da mesma forma, é interessante analisar o quanto a vivência dessa espacialidade interfere de forma ativa nas práticas cotidianas de sujeitos mesmo após o período de encarceramento, condicionando seus corpos e comportamentos.

Foucault (2007) apresenta a evolução do sistema penal na sociedade em suas múltiplas facetas. Para o autor, a base desse sistema está fundamentada em mecanismos para se fazer punir, articulados 
pela sociedade, chamados pelo autor de dispositivos de vigilância, os quais são produtos de determinados contextos políticos, econômicos e culturais, se modificando, da mesma forma, mediante a mudança da sociedade. Para o autor, a prisão, em sua forma atual, foi uma longa e lenta evolução das formas de punição elaboradas e repensadas ao longo da história da sociedade moderna .

Em sua genealogia sobre as formas de poder e punição, ele afirma que a prisão no sistema penal dos séculos XVII e XVIII não se apresentava enquanto uma pena do direito, ou seja, quando a lei punia um determinado indivíduo, sua punição seria a condenação a morte, a ser marcado, banido, etc.. A prisão não era uma punição. A extinção das formas de punições corpóreas, denominadas de suplício, foi a característica fundamental para a mudança em toda a maquinaria punitiva no século XVIII. O corpo, supliciado, marcado simbolicamente, era o alvo dos dispositivos de punição. O corpo como espetáculo, como garantia de exemplo social.

Carvalho Filho (2002) discute que a origem das prisões está intimamente relacionada não com a punição em si, mas com a garantia para que ela ocorra. Como discute o autor, os réus não eram condenados a perda de sua liberdade. Mas sim, eram privados dela para viabilizar a punição imposta, que ia de realização de trabalhos forçados até a pena de morte. Nesse sentido, não havia necessidade de se preocupar com as condições de vivência nas prisões, bastava que fossem inexpugnáveis. É interessante observar que, ainda hoje, as condições dos espaços carcerários são precárias.

A partir do século XVIII, a natureza da prisão se modifica, assemelhando-se cada vez mais com o modelo instituído que conhecemos atualmente. Com as novas necessidades econômicas surge também a necessidade de se considerar a 'humanidade' até dos piores assassinos. Esquecemos os corpos e passamos então para as almas. Essa é como discute Foucault (2007), a principal característica da nova economia do poder. A privação da liberdade, direito garantido a todos, se transforma na mais moderna e humana forma de punição. Com essa nova configuração dos dispositivos de punição, surge a chamada forma - prisão, com moldes que permanecem até hoje. Nas palavras do autor,

A forma-prisão preexiste à sua utilização sistemática nas leis penais. Ela se constitui fora do aparelho judiciário, quando se elaboram, por todo o corpo social, os processos para repartir os indivíduos, fixálos e distribuí-los espacialmente, classificá-los, tirar deles o máximo de tempo, e o máximo de forças, treinar seus corpos, codificar seu comportamento contínuo , mantê-los numa visibilidade sem lacuna, formar em torno deles um aparelho completo de observação, registro e notações, constituir sobre eles um saber que se acumula e se centraliza. (FOUCAULT, 2007, p. 195)

Uma das finalidades desse novo sistema é a vigilância. Percebe-se então, que é mais lucrativo vigiar do que punir. Ou seja, percebe-se que os delinqüentes têm uma finalidade. Então, por que dilacerarmos seus corpos, tornando-os assim, inúteis para qualquer outro tipo de atividade? É isso que Foucault (1969) mostra. O reajustamento nas formas de punição, essa nova mecânica do poder que vê nos corpos encarcerados, novas utilidades. A partir disso, o autor compreende que a prisão sempre esteve ligada a um processo baseado na transformação de indivíduos, no treinamento de seus corpos, na readequação de sua conduta, conduta essa que deve ser compatível com as configurações socioespaciais vigentes. Nas palavras do autor,

Minha hipótese é que a prisão esteve, desde sua origem, ligada a um projeto de transformação dos indivíduos. Habitualmente se acredita que a prisão era uma espécie de depósito de criminosos, depósito cujos inconvenientes se teriam constatado por seu funcionamento, de tal forma que se teria dito ser necessário reformar as prisões, fazer delas um instrumento de transformação dos indivíduos. Isto não é verdade: os textos, os programas, as declarações de intenção estão aí para mostrar. Desde o começo a prisão devia ser um instrumento tão aperfeiçoado quanto à escola, a caserna ou o hospital, e agir com precisão sobre os indivíduos. $O$ fracasso foi imediato e registrado quase ao mesmo tempo que o próprio projeto. Desde 1820 se constata que a prisão, longe de transformar os criminosos em gente honesta, serve apenas para fabricar novos criminosos ou para afundá-los ainda mais na criminalidade. 
Foi então que houve, como sempre nos mecanismos de poder, uma utilização estratégica daquilo que era inconveniente. A prisão fabrica delinqüentes, mas o delinqüentes são úteis tanto no domínio econômico como no político. (FOUCAULT, 1969, p. 131-132)

Essa idéia apresentada por Foucault (1969) é muito semelhante à apresentada por Goffman (1988). O espaço carcerário faz parte do que o autor denomina de 'instituições totais', ou seja, um local onde certo número de indivíduos é mantido afastado da sociedade por um determinado período de tempo levando uma vida regrada e formalmente administrada. Para Goffman (1988), as instituições totais são discordantes a diversos aspectos da vida social, tais qual a família, as redes de relacionamentos pessoais e também as características que formam e instituem identidades dos sujeitos.

Goffman (1988) discute que existem cinco tipos fundamentais de instituições classificadas por ele como 'totais', as quais podem ser divididas nas seguintes categorias,

Em primeiro lugar, instituições criadas para cuidar das pessoas que, segundo se pensa, são incapazes e inofensivas; nesse caso estão as casas para cegos, velhos, órfãos e indigentes. Em segundo lugar, há locais estabelecidos para cuidar de pessoas consideradas incapazes de cuidar de si mesmas e que são também uma ameaça à comunidade, embora de maneira não intencional; sanatórios para tuberculosos, hospitais para doentes mentais e leprosários. Um terceiro tipo de instituição total é organizado para proteger a comunidade contra perigos intencionais, e o bem-estar das pessoas assim isoladas não constitui o problema imediato: cadeias, penitenciárias, campos de prisioneiros de guerra, campos de concentração. Em quarto lugar, há instituições estabelecidas com a intenção de realizar de modo mais adequado alguma tarefa de trabalho, e que se justificam apenas através de tais fundamentos instrumentais: quartéis, navios, escolas internas, campos de trabalho, colônias e grandes mansões (do ponto de vista dos que vivem nas moradias dos empregados). Finalmente, há os estabelecimentos destinados a servir de refúgio do mundo, embora muitas vezes sirvam também como locais de instrução para os religiosos; entre exemplos de tais instituições, é possível citar abadias, mosteiros, conventos e outros claustros. (GOFFMAN, 1988 p. 16-17)

Goffman (1988) afirma que esses cinco modelos fundamentais de instituições podem ser concebidos enquanto híbridos sociais, ou colocando de outra forma, como experimentos naturais do que se pode fazer com as identidades individuais. Esta questão foi, pois, fortemente explorada pelo autor, uma vez que, sua idéia central é de que essas instituições, e no caso dessa pesquisa, as prisões, são constituídas de forma a, se não destruir completamente, ao menos deteriorar as características identitárias dos 'internados' no momento de sua chegada.

Obviamente, não devemos deixar de levar em consideração que a espacialidade carcerária é, antes de tudo, construída a partir das práticas cotidianas dos sujeitos que estão diretamente envolvidos em sua dinâmica, ou seja, os próprios encarcerados. Esses sujeitos produzem dissonâncias, irregularidades a partir táticas que burlam toda a normatividade instituída pela administração formal. Paradoxalmente, os condicionamentos impostos pela rigidez da espacialidade carcerária são fortemente absorvidos, seguindo com os encarcerados mesmo após o período de prisão (FIORAVANTE, 2011).

Lembramos, nesse momento, das proposições de Foucault (2007), quando o autor afirma que as prisões sempre estiveram associadas à idéia de transformação dos indivíduos, e da mesma forma, o quanto os mecanismos de poder são capazes de adentrar nos corpos dos indivíduos inseridos na maquinaria punitiva. Concebemos o espaço carcerário como sendo construído a partir de múltiplos feixes de relações, apresentando, por conseguinte, relações de poder muito peculiares, provenientes de várias "direções", modelando, controlando, regulando não somente as práticas cotidianas dos sujeitos, mas também, sua corporalidade. Em pesquisa realizada com as mulheres encarceradas na cidade de Ponta Grossa, conseguimos concluir o quanto esse condicionamento é forte, causando nas mulheres sentimentos como medo e repulsa pelo espaço urbano da cidade após sua libertação. 
Kantrowitz (1996) dedicou interesse as dinâmicas corpóreas em um presídio de segurança máxima, chegando à conclusão que é graças ao rígido controle corporal que um espaço carcerário é controlado. O regime penitenciário é, desta forma, dependente dos corpos dos prisioneiros, de sua localização, de sua distribuição. O resultado disso, segundo Philo (2009) é uma geografia corporal da prisão.

Como lembra Foucault (2007) à questão corpórea sempre foi central ao longo de toda a construção dos mecanismos punitivos, seja a partir do corpo do monarca, representação máxima da ordem e do poder, da importância dada ao corpo supliciado, exemplo social até mesmo a observação, vigilância para atingir a docilidade dos corpos dos condenados. A disciplina procede então, da distribuição de indivíduos pelo espaço. Vale à pena citar Foucault (2007),

Cada indivíduo tem o seu lugar; e cada lugar o seu indivíduo. Evitem-se as distribuições em grupos; dividam-se disposições coletivas; analisem-se pluralidades confusas, massivas ou transitórias. O espaço disciplinar tender a ser dividido em tantas seções quanto os corpos ou elementos a ser distribuídos. Devem-se eliminar os efeitos das distribuições imprecisas, o desaparecimento descontrolado dos indivíduos, a sua circulação difusa, a sua coagulação instável e perigosa. O objetivo é estabelecer presenças e ausências, o saber localizar indivíduos, e saber construir comunicações úteis, interromper os outros, saber supervisionar em cada momento a conduta de cada indivíduo, assistir, julgar, calcular as suas qualidades ou méritos. Deste modo, é um procedimento que procura saber, dominando e usando. A disciplina organiza um espaço analítico . (FOUCAULT, 2007, p. 143)

A experiência da prisão modifica completamente a construção que essas mulheres criam de si mesmas, da sociedade e do mundo. A vivência dessa espacialidade gera seqüelas emocionais, alterando a subjetividade e a forma de percepção dessas mulheres da realidade social. Os processos de readaptação a uma vida fora da prisão são lentos e embebidos em sentimentos como medo, angústia e desaprovação. É isso que vamos explorar nas próximas seções desse artigo, a partir do perfil e do processo de re-inserção socioespacial das mulheres que passaram pelo sistema penitenciário na cidade de Ponta Grossa, Paraná.

\section{O PERFIL E O PROCESSO DE RE-INSERÇÃO SOCIOESPACIAL DAS MULHERES EGRESSAS NA CIDADE DE PONTA GROSSA, PARANÁ}

Para construção dessa seção utilizamos os dados que foram coletados em trabalho de campo realizado com as mulheres egressas na cidade de Ponta Grossa durante o ano de 2010, no qual foram entrevistadas oito mulheres para compreender como se deu a experiência de seu encarceramento, bem como, a forma como ocorreu seu processo de re - inserção socioespacial após a pena de prisão.

Antes de continuarmos, é interessante fazer uma pequena pausa para esclarecer o que qualifica uma pessoa como egressa. A definição oficial do termo 'Egresso', é definido pela Lei de Execuções Penais número 7.210/84, artigo 26. A partir dessa lei, pode-se caracterizar uma pessoa egressa como o liberado definitivo do cárcere, pelo prazo de um ano a partir da saída do estabelecimento, e também, o liberado condicional, ainda em período de prova de pena. É interessante apontar que existem instituições que são responsáveis por prestar auxílio a essas pessoas, ajuda essa garantida por lei. Na cidade de Ponta Grossa, o Programa Pró - Egresso, criado em 1985 é responsável por proporcionar acompanhamento aos egressos após o período de encarceramento.

Em uma coleta realizada nos arquivos do Programa Pró - Egresso no ano de 2007, podemos concluir que houve um aumento considerável na ocorrência de crimes cometidos por mulheres na cidade de Ponta Grossa. O gráfico a seguir, construído com base nesses dados demonstra esse crescimento.

Como podemos observar no gráfico, houve um grande aumento do número de mulheres que estão envolvidas com práticas criminosas na cidade de Ponta Grossa, crescimento este de aproximadamente $527 \%$ em apenas sete anos. Esses dados são referentes não apenas às mulheres que 
estiveram encarceradas, mas também às mulheres que estavam cumprindo penas restritivas de direito, as chamadas penas alternativas, conhecidas pela sociedade como serviços comunitários. Do universo total de dados coletados no PPE, ou seja, um total de 404 casos, observamos que somente $15 \%$ desse total se relacionava com mulheres que tinham passado pelo sistema penitenciário. Essas mulheres apresentam um perfil socioespacial diferenciado das mulheres que cumprem penas restritivas de direito. Elas têm menor escolaridade, menor renda, maiores índices de envolvimento com entorpecentes e têm sua vivencia cotidiana em espacialidades de bairros da periferia da cidade.

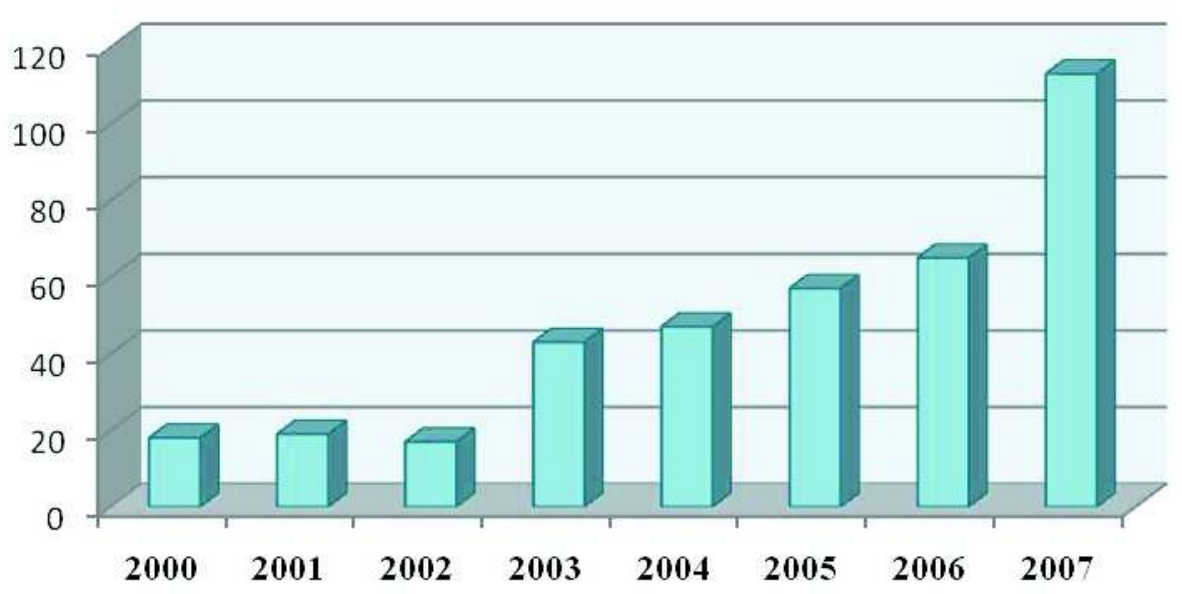

Figura 2 - Gráfico do Crescimento do número de mulheres com práticas delituosas na cidade de Ponta Grossa, Paraná

Fonte: Programa Pró - Egresso, Ponta Grossa - PR Organização: FIORAVANTE, K.E. 2008

Esse perfil é compatível com o que obtivemos nas entrevistas com as oito mulheres egressas. A maioria é jovem, ou seja, $75 \%$ têm idade até 40 anos. Apresentam, da mesma forma, baixa escolaridade, sendo que $62,5 \%$ possuem apenas o primeiro grau incompleto. Apenas uma delas não é mãe, sendo que $75 \%$ têm mais de três filhos. O problema do exercício da maternagem é com certeza uma das mais interessantes especificidades da criminalidade e do cárcere mulheres, uma vez que seus filhos costumam estar, direta ou indiretamente, envolvidos em suas dinâmicas criminais.

A vivência do espaço carcerário é relatada como de afastamento dos espaços anteriormente vivenciados. A família se re-organiza e, em geral, a mulher encarcerada acaba sendo substituída por outra, tanto em relação aos relacionamentos maritais quanto maternais. As visitas de parentes e membros da família ao espaço do cárcere a fim de manter os vínculos das redes familiares são dificultadas. Há casos em que as próprias mulheres evitam as visitas de filhos, a fim de protegê-los do constrangimento das revistas realizadas por policiais que exigem a retirada de roupas e, inclusive, averiguação dos corpos. Os cônjuges e parceiros amorosos também se afastam. Com o passar do tempo, constroem novos relacionamentos e abandonam as mulheres que vivem em situação de cárcere.

As relações maternas também são prejudicadas em função da falta de infra-estrutura adequada nos presídios femininos. No estado do Paraná, há 448 vagas para mulheres, segundo o relatório realizado pelo Departamento Penitenciário Nacional em abril de 2008. A penitenciária feminina do Paraná se destina ao cumprimento de pena em regime fechado e possui uma creche com capacidade para 40 crianças e um berçário para 12 crianças.

Com relação ao estado civil, podemos observar que algumas das mulheres conseguiram reconstruir sua vida marital, sendo que $50 \%$ se declaram casadas ou amasiadas, ou seja, em relacio- 
namento estável, mas não reconhecido legalmente. É interessante apontar que a vivência do espaço carcerário é relatada como de quebra dos laços afetivos com os companheiros. Observamos que as mulheres, quando são libertadas, acabam por reconstruir suas vidas com outros companheiros, reconstruindo novos laços românticos.

Com relação aos delitos cometidos, duas delas foram condenadas por ter cometido homicídio, artigo 121 do Código Penal Brasileiro e uma, pelo artigo 218 da Lei 12.015/09, que se caracteriza da seguinte forma, "induzir alguém menor de 14 (catorze) anos a satisfazer a lascívia de outrem", ou seja, induzir menor à prostituição. O restante, $62 \%$ do total esteve encarcerada por envolvimento com entorpecentes, seja enquanto usuárias de drogas ou traficantes.

Segundo dados do Ministério da Justiça, encontram-se presas no Brasil 4451 mulheres por tráfico de entorpecentes e outras 186 por tráfico internacional. De acordo como DEPEN, até junho de 2009, estavam presas no estado do Paraná 334 mulheres por envolvimento com drogas, sendo 310 delas por tráfico de entorpecentes (artigo 12 da Lei 6.368/76 e artigo 33 da Lei 11.346/06) e o restante, por tráfico internacional de drogas (artigo 18 da Lei 6.368/76). Na cidade de Ponta Grossa, $30 \%$ das mulheres egressas atendidas pelo Programa Pró - Egresso - PPE - durante os anos de 2000 a 2007 estiveram encarceradas por tráfico de drogas.

Cada vez mais, as mulheres vêm se encaixando na dinâmica do tráfico de drogas, tanto em papéis subalternos quanto em posições de maior poder, como evidenciam os trabalhos de Souza (2000), Pimentel (2008) e Soares e Ilgenfritz (2000). O crescente envolvimento feminino no tráfico de drogas tem sido relacionado com os laços afetivos entre as mulheres e homens traficantes, evidenciando que essas mulheres ocupariam um papel subalterno em relação ao parceiro afetivo traficante. Pimentel (2008) analisou os laços de afetividade que levaram as mulheres presas no estado de Alagoas à criminalidade e ao tráfico. A autora trabalha com a perspectiva de que o amor romântico tem grande peso, geralmente significativo, na decisão das mulheres em entrar na dinâmica do tráfico de drogas.

A afetividade é uma condição incontestável da experiência humana, sendo supervalorizada nas vivências femininas. A sociedade ocidental é marcada por um modelo ideal de amor - paixão. Lipovetsky (2000) discute a construção ocidental do amor e conclui que mesmo com todas as posturas revolucionárias das mulheres no século XX, esse sentimento de amor ideal permanece inabalado. Nas palavras de Lipovetsky (2000),

Nenhuma ilusão: mesmo na exaltação do período contestador, as mulheres jamais renunciaram aos sonhos de amor. O discurso sentimental se tornou eufemístico, não as experiências e os valores amorosos. O novo ceticismo em relação à retórica romântica e a sexualização dos discursos não correspondem ao recuo das esperanças amorosas mas à rejeição das convenções 'falsas', bem como à promoção dos valores de proximidade e de intimidade, à intensificação da necessidade de uma comunicação mais autêntica. (LIPOVETSKY, 2000, p. 28)

A identidade feminina é construída culturalmente e marcada por determinados papéis e comportamentos sociais, os quais, a sociedade espera encontrar em uma mulher (SILVA, 2009). A passividade, a gentileza e também o romantismo. As mulheres encarceradas valorizam o amor romântico e de acordo com a perspectiva de Pimentel (2008), também embarcam no tráfico de drogas por amor ao companheiro.

M. Souza (2000) discute que o consumo e o tráfico de drogas são fenômenos recentes no Brasil. O autor afirma que a década de 1980 foi decisiva para o aumento incessante do número de usuários dessas substâncias, e conseqüentemente, do número de sujeitos envolvidos no sistema de varejo e consumo. O geógrafo discute que essa dinâmica ocorre nas cidades dos mais diversos portes, utilizando em larga escala, espaços pobres como favelas e áreas periféricas como base de apoio logístico. No caso da cidade de Ponta Grossa, isso não difere, ocupando posição central na dinâmica do tráfico de drogas as áreas periféricas e menos assistidas pelo poder público. 
O geógrafo continua sua discussão trazendo a hierarquia espacial e a divisão do trabalho existente na dinâmica do tráfico de drogas. Segundo o autor, essa divisão que envolve diversos atores sociais é organizada através de relações de poder, na medida em que cada ator possui uma participação diferente nos ganhos do negócio. Tomando como exemplo as quadrilhas de traficantes de drogas das favelas da metrópole do Rio de Janeiro, o autor identificou os diferentes papéis envolvidos na dinâmica do tráfico de drogas,

O chefete local é o "dono", o qual controla diversos pontos de vendas de tóxicos ("bocas de fumo"). Uma vez que os "donos" cada vez menos moram em favelas e sim no "asfalto" (ainda que tenham origem favelada), quem responde pelo negócio em um dado local é o "gerente", o qual realiza a contabilidade, supervisiona o pessoal da segurança e realiza diversos contatos em nome do "dono". Além do "dono" e de seus "gerentes" há os "soldados", que são aqueles indivíduos que, fortemente armados, garantem a segurança do negócio, impondo a "ordem" na favela e defendendo os pontos de venda de um "dono" contra as tentativas de captura realizada por outras quadrilhas. Há, também, os "olheiros", que são aqueles que avisam sobre a aproximação da polícia ou de "alemães" (estranhos, inimigos), e os "aviões" e "aviõezinhos", que entregam droga aos clientes, os quais muitas vezes aguardam na entrada da favela dentro de seus carros. (SOUZA, 2000, p. 57)

As mulheres vêm gradativamente se encaixando nessa dinâmica, mas diferentemente dos homens, elas ocupam, geralmente, posições subalternadas, ou utilizando as nomeações propostas por Souza (2000), podemos enquadrá-las como 'aviões', raramente conseguindo galgar posições de maior poder. É possível, portanto, afirmar, que mesmo em atividades ilegais, as desigualdades de gênero persistem.

Moura (2005) estudou a participação feminina no tráfico de drogas na penitenciária feminina do estado do Ceará. A autora observou que as desigualdades de gênero presentes no mercado de trabalho também estão presentes na dinâmica do tráfico de droga. Ela discute que $81,4 \%$ das mulheres entrevistadas em sua pesquisa, disseram ter papéis subalternos, como entregadoras, embaladoras ou fazendo uma micro-comercialização, ou seja, usam uma parte de droga e a restante, vendem para conhecidos. Moura (2005) afirma que,

O tráfico de drogas passa a representar uma real estrutura de oportunidades para as mulheres, não só pela oportunidade de um retorno financeiro imediato, mas também pela predominância da informalidade do mercado e a virtual ausência de barreiras ao ingresso de mão-de-obra feminina nesse mercado. Alia-se a tudo isso o fato de que essa atividade remete, de alguma forma, para a esfera doméstica, espaço que as mulheres dominam e onde se identificam. (MOURA, 2005, p. 126)

A participação feminina na dinâmica do tráfico de drogas acontece principalmente pela situação de invisibilidade que essa população de baixa renda vive frente ao poder público. Não objetivamos adotar uma postura vitimista, entretanto, não podemos deixar de apontar que grande parte dessas mulheres são desprovidas de assistência e sem meios de garantir sua sobrevivência e de seus filhos, buscam caminhos mais rápidos, como o tráfico de drogas.

O tempo de encarceramento das mulheres com as quais dialogamos varia de dois anos, o mais longo deles, até três meses . Com relação à quantidade de vezes que esteve detida, apenas uma delas nos relatou que esteve presa por quatro vezes. $O$ restante não teve reincidências após a soltura. São, $50 \%$ delas provenientes do mesmo local da cidade de Ponta Grossa, a vila Quero-Quero. O restante mora nos seguintes bairros e vilas: Borsato, Santo Antonio, Boa Vista e Centro.

Como já afirmamos, a experiência do encarceramento muda a maneira como essas mulheres constroem sua visão com relação a inúmeros aspectos de sua vida. Da mesma forma, concluímos, a partir de suas falas, o quanto os condicionamentos criados, não apenas em seus comportamentos subjetivos, mas também em seus corpos, permanece remodelando suas atitudes após o período de encarceramento. Essa é apenas uma, das inúmeras, dificuldades que essas mulheres enfrentam no 
momento de reconstrução de seu cotidiano pós-cárcere. O processo de re-inserção socioespacial é conflituoso, e mesmo apesar de existirem instituições que, em teoria deveriam amenizar suas dificuldades, na prática esse dinâmica ocorre de forma solitária e não assistida.

Os debates acerca da re-inserção de egressos há muito instiga profissionais das mais diversas áreas, como criminalistas, sociólogos, psicólogos entre outros. Entretanto, a idéia de re-inserção, ou re-socialização, pode ser concebida enquanto um conceito plural e vago, visto que existem inúmeras concepções desenvolvidas para caracterizar esse período de fim da pena de prisão, bem como, são apontados diversos 'mecanismos' através dos quais o Estado seria, ou deveria ser, capaz de prover ao indivíduo egresso uma real condição de reintegração à sociedade. A discussão acerca da re-inserção nos põe da mesma forma, a necessidade de refletir acerca do propósito da pena de prisão, vista atualmente não como castigo, mas sim, como uma forma humanitária de punição.

De Jesus (1999) refere-se ao modelo re-socializador enquanto um sistema de reabilitação social, no qual a prisão e a pena privativa de liberdade não são um instrumento de vingança, mas sim, um meio de corrigir um comportamento ilícito e criminoso visando a reinserção do indivíduo na sociedade. Molina e Gomes (1997) afirmam que nesses termos,

O modelo ressocializador propugna, portanto, pela neutralização, na medida do possível, dos efeitos nocivos inerentes ao castigo, por meio de uma melhora substancial ao seu regime de cumprimento e de execução e, sobretudo, sugere uma intervenção positiva no condenado que, longe de estigmatizá-lo com uma marca indelével, o habilite para integrar-se e participar da sociedade, de forma digna e ativa, sem traumas, limitações ou condicionamentos especiais. (MOLINA e GOMES, 1998, p.383)

É possível afirmar que o processo de re-socialização, a despeito de seu caráter ambíguo, preza a idéia de humanização, ou seja, um sistema que proporcione ao preso condições efetivas para reintegração à sociedade, e que, da mesma forma, evite a reincidência criminal. Como discutem Molina e Gomes (1997), essa meta visa dissolver os efeitos perversos da pena de prisão, evitando a estigmatização do presidiário.

O direito à re-socialização do preso está vinculado à política criminal, tendo como base o ordenamento jurídico dos direitos fundamentais dos indivíduos, estando previsto no artigo 41 da Lei de Execuções Penais (LEP), onde adquire caráter de tratamento educativo. De acordo com Ancel (2007), esse direito do presidiário deve iniciar no momento de seu encarceramento, ou seja, o regime penitenciário deve garantir ao detento a possibilidade gradativa de re-socialização. Entretanto, na prática e na situação atual do sistema carcerário brasileiro, essas proposições podem soar mesmo como demagogia.

Baratta (1997) defende o uso da terminologia reintegração social, uma vez que para o autor, esse conceito possibilitaria uma maior comunicação entre a prisão e a sociedade, evitando dessa forma, a invisibilidade e negligência do restante da população com os encarcerados. Na mesma perspectiva Falconi (1998) defende que o uso do termo 're-inserção' social é o mais apropriado. Segundo ele, a idéia de maior comunicação entre a sociedade e o cárcere implica em um menor preconceito no momento de soltura do presidiário, amenizando sua dificuldade de reintegração a vida social e até, diminuindo, portanto, a re-incidência criminal.

Entretanto, Baratta (1997) discute que o modelo re-socializador está falido, uma vez que através de observações empíricas constataram-se inúmeros problemas estruturais e mínimos progressos alcançado pelo sistema penitenciário no Brasil. Nas palavras do autor,

Como mostra a atual realidade carcerária, os requisitos necessários para o cumprimento de funções de ressocialização, unidos aos estudos dos efeitos do cárcere sobre a carreira criminal - pense-se na alta cota de reincidência -, têm invalidado amplamente a hipótese de ressocialização do delinqüente através do cárcere. (BARATTA, 1997, p.75). 
O processo de reabilitação do presidiário é dificultado, e muitas vezes, impossibilitado devido ao fato de que a pena de prisão estigmatiza o recluso. Essa questão do estigma será discutida de forma mais densa posteriormente. Da mesma forma, é interessante apontar que esses modelos re-socializadores que prezam a maior comunicação entre o cárcere e a sociedade são ambíguos. A princípio parece uma interessante forma de diminuir o desmazelo vivenciado pela população encarcerada. Entretanto, parece discordante segregar um indivíduo, em um espaço hostil e desfavorável, e ao mesmo tempo, visar sua reintegração na sociedade. Ainda mais quando recordamos as proposições de Goffman (1988), já discutidas no primeiro capítulo desse trabalho, acerca da construção dessas instituições. Bittencourt (2004) reafirma essa proposição, discutindo que essas instituições se transformam em uma espécie de microcosmos, na qual todas as discrepâncias e relações de desigualdade social acabam se reproduzindo no espaço carcerário.

Rodrigues (1987) propõe um conceito de re-socialização que vem sendo bem aceito na esfera jurídica e criminal, no qual preza os meios necessários para o preso se re-inserir na sociedade. Para a autora, esses meios não se diferem dos utilizados na sociedade externa, uma vez que, enfoca-se o trabalho como principal meio de estabilização social. Nas palavras da autora o programa de re-socialização deve ser constituído de forma,

(...) que visa integrar o indivíduo no mundo dos seus concidadãos, sobretudo nas coletividades sociais básicas como, por exemplo, a família, a escola ou o trabalho, proporcionando o auxílio necessário que o faça ultrapassar a situação de defasamento social em que se encontra. (RODRIGUES, 1982, p. 29)

É possível recordar das proposições de Elias (1970) e Wiese (1933) nesse momento, os quais exploram o conceito de socialização como um processo contínuo, ou seja, sempre em construção e modificação. Não é raro escutarmos debates acerca da temática 're-socialização' ou 're-inserção' que sejam dirigidos de forma a remeter-se a idéia de uma nova socialização, de retomada de algo interrompido. Essa concepção é discordante da idéia de socialização como processo, sempre em continuidade. Adotamos, portanto, a expressão 'reintegração social', utilizando da mesma forma a idéia durkhemiana que faz alusão a condição em que um sujeito retoma sua posição em um grupo que pertença, ou no caso dessa reflexão, da mesma forma, a uma espacialidade de sua vivência anterior. É a partir dessa noção que vamos discutir as experiências de reintegração social e reestruturação da vida cotidiana das mulheres egressas na cidade de Ponta Grossa

A partir da análise das falas das mulheres egressas, realizada por meio da identificação de categorias discursivas, observamos determinados elementos que foram mais evocados pelas mulheres, os quais representam as maiores dificuldades que elas encontraram para reconstruir suas vidas após o encarceramento. Esses desafios estão relacionados com o afastamento sentimental de familiares, com a impossibilidade de se conseguir um emprego após o cárcere, bem como, a estigmatização que essas pessoas sofrem quando vivem determinadas relações socioespaciais.

A reconstrução da vida social e econômica foi a mais presente nas falas das mulheres egressas. Também observamos que essa situação é, em parte, agravada pelo afastamento dos filhos, o que provoca nessas mulheres uma desestabilização ainda maior. $\mathrm{O}$ medo da cidade, do espaço urbano, o qual tem representações de liberdade e vulnerabilidade, também foram citados pelas mulheres. Podemos recordar as discussões de Foucault (2007) acerca dos efeitos dos mecanismos de poder nos corpos dos encarcerados, como já discutimos na seção anterior desse artigo.

As mulheres, após o encarceramento, continuam realizando determinadas ações as quais estão diretamente relacionadas com a espacialidade carcerária que vivenciavam, demonstrando o quanto os condicionamento da maquinaria punitiva foi absorvido, controlando, mesmo que de forma indireta, seus corpos após o período de prisão. São atos como sentarem-se com as pernas encolhidas, manterem suas casas fechadas, escuras, criando uma espécie de reprodução da espacialidade do cárcere. É interessante observar que, na grande maioria das vezes, essas ações são feitas de forma 
inconsciente, ou seja, são tão "naturais" para as mulheres que elas só se dão conta quando são questionadas com relação a isso.

A discriminação que as egressas sofreram também aparece enquanto categoria expressiva, uma vez que $75 \%$ do total de mulheres afirmaram que sentiram que foram discriminadas, ou tratadas de forma diferente, após retornarem à cidade. Essa reflexão, nos remete, necessariamente, as discussões acerca do conceito de estigma propostas por Goffman (1963). Segundo o autor, esse termo já era utilizado pelos gregos para se referir a sinais corporais que representavam aspectos negativos da conduta moral de quem os possuía. Os sinais feitos com fogo ou cortes remetiam então a determinados tipos de identidades como criminosos, traidores e escravos. Atualmente, não se remetem apenas a marcas nos corpos, mas sim, a noções identitárias mais subjetivas, como no caso de uma pessoa que foi encarcerada.

Nossa sociedade construiu mecanismos ao longo de sua história para classificar, categorizar e enquadrar atributos que são considerados como comuns e naturais em sujeitos . O termo estigma, portanto, representa um atributo depreciativo, o qual leva o indivíduo a ser menos aceito socialmente. Goffman (1963) aponta que existem três tipos fundamentais de estigmas. Nas palavras do autor,

Podem-se mencionar três tipos de estigma nitidamente diferente. Em primeiro lugar, há as abominações do corpo - as várias deformidades físicas. Em segundo, as culpas de caráter individual, percebidas como vontade fraca, paixões tirânicas ou não naturais, crenças falsas e rígidas, desonestidade, sendo essas inferidas a partir de relatos conhecidos de, por exemplo, distúrbio mental, prisão, vício, alcoolismo, homossexualismo, desemprego, tentativas de suicídio e comportamento político radical. Finalmente, há os estigmas tribais de raça, nação e região, que podem ser transmitidos através de linhagem e contaminar por igual todos os membros de uma família. (GOFFMAN, 1963, p. 14)

Da mesma forma, o autor afirma que o termo estigma está inserido em duas perspectivas. A primeira delas, a qual ele chama de condição de desacreditado, se dá quando o estigmatizado assume que sua característica já é conhecida, ou imediatamente perceptível, como no caso de uma marca corpórea. A segunda, a condição de desacreditável, na qual seu estigma não é visivelmente perceptível. Podemos, entretanto, ousar e afirmar que um egresso ocupa, mediante sua espacialidade, essas duas condições. Em sua residência, com sua família, por exemplo, a qual está ciente de seu encarceramento, ele ocupa a posição de desacreditado. Entretanto, nos espaços públicos, a busca de um emprego, ele pode ser classificado como desacreditável.

A dificuldade de acesso ao mercado de trabalho é apenas um dos problemas que as pessoas egressas enfrentam para recompor suas vidas. A questão familiar também está presente. A perda dos laços familiares, em alguns casos, é permanente, implicando em afastamentos, se não corporais, sentimentais.

Da mesma forma, os preconceitos e discriminações que esses indivíduos sofrem são imensos. Em uma perspectiva foucaultiana, Velho (1985) lembra que os 'desviantes' e sua situação social foram encarados em uma perspectiva médica, chegando a última ser interpretada como uma patologia. Ou seja, certas pessoas apresentam características comportamentais classificadas como 'anormais', sintomas de doenças e desequilíbrios, necessitando, portanto, de tratamento. Essa concepção dá idéia de um total afastamento do indivíduo do processo social, cultural e espacial da construção de sua identidade. Goffman (1963) afirma que,

Nos muitos casos em que a estigmatização do indivíduo está associada com sua admissão a uma instituição de custódia, como uma prisão, um sanatório ou um orfanato, a maior parte do que ele aprende sobre seu estigma ser-lhe-á transmitida durante o prolongado contato íntimo com aqueles que irão transformar-se em seus companheiros de infortúnio. (GOFFMAN, 1963, p. 46)

É interessante observar nessa proposição de Goffman (1963) o intrínseco caráter espacial do estigma, podendo este mesmo ser diferenciado a partir da espacialidade através da qual é construído. Da mesma forma, pode ser mais ou menos visível, mais ou menos brando. 
Adorno e Horkeimer (1985) apontam que a humanidade foi construída a partir de uma dicotomização entre 'salvadores' e 'condenados', dicotomia esta, que poderia ser expandida a partir de antônimos como deficientes e não deficiente, criminosos e não - criminosos. Para os estigmatizados, a sociedade reduz oportunidades, determina uma imagem deteriorada, discordante com o modelo que convém a esse mesmo modelo social, assumindo a condição de nocividade, incapacidade. A fala de uma das egressas demonstra a dificuldade de reintegração ao mercado de trabalho, devido a sua condição de ex-presidiária,

Ontem mesmo eu tava conversando com duas clientes, a cliente falou assim, elas não falaram pra mim, pra não me magoar, mas entre elas conversando: imagine, perguntaram pra mim onde eu to fazendo a massagem, eu falei que era com a Paula. Qual Paula? Com aquela ali de cima, que teve problema, foi presa. E a outra disse assim, ui, mas você tem coragem de faze lá com ela. Aí ela falou: ué que que tem, ela não vai me passa nada. Um dia uma outra falou assim, ixi, nem ligue, esses dia eu vim no ônibus com uma que falou que deus o livre se o marido soubesse que ela tá fazendo massagem aqui com a Paula. Entendeu, você vê que por mais que as pessoas não falem na tua cara, as pessoas são preconceituosas. São preconceituosas de vim aqui porque sabem que eu fui uma presa, então quando eu passo, eu passo e não do bola, mais do que nunca, pras pessoas. Porque elas olham, querendo ou não. Elas acabam falando entre elas. Imagine, o marido dela descobrir que vem aqui porque eu sou né, que eu tenho uma mulher, que eu vo mexe, alguma coisa. Então é um preconceito por eu ser homossexual, comigo mesmo e o preconceito de eu ser presa. Então, são coisas que pesam bastante. Eu tenho bastante cliente que, ainda tá frio, que no começo eu sei que vai mais devagar, mas eu to tendo cliente assim, São Marcos, Quero - Quero, redondeza, pessoas que não me conhecem. Olha, o Borsato é grande. São pouquíssimas pessoas que eu tenho no Borsato, porque são pessoas que me conhecem. Se não vêem, é por um grau de preconceito.

Podemos, da mesma forma, perceber o quanto a noção de estigma perpassa pelo corpo social, sendo percebida mesmo, nas questões relacionadas às sexualidades. E indo além, o quanto nossa sociedade é capaz de imprimir em um mesmo corpo, várias formas de estigma. Quando questionamos a entrevistada para descobrir qual era, em sua opinião, o preconceito mais significativo, obtivemos a seguinte resposta,

A maioria eu acho que um bom tanto, tipo, geral, é por ser presa. Porque como naquela época ninguém imaginava e eu era uma traficante, hoje eles podem acha também que eu so traficante e isso aqui é uma fachada. Entre as mulheres eu creio que é um pouco de preconceito, de algumas né, outras não, de eu ser. Preconceitos ou delas ou não dos maridos que acham que faze massagem em alguém vai passa alguma coisa. Então, na verdade eu sofro o dobro.

Goffman (1963) também discute que as pessoas representam papéis sociais, de acordo com as convenções sociais. Podemos acrescentar a essa proposição, que essa atuação se dá de acordo com a espacialidade a qual vivenciam . O preconceito pode ser da mesma forma, observado em todas as esferas de atuação do indivíduo. Conseguimos observar da mesma forma, que a noção de estigma e o preconceito ultrapassam somente o corpo e a moral do indivíduo que vivenciou o cárcere, sendo também, estendida em algumas ocasiões aos filhos e familiares das detentas. Schilling e Miyashiro (2008) discutem que o preconceito é presente aos filhos de ex - presidiários em sua vida cotidiana. Para as autoras, a sociedade observa esses indivíduos de forma fundida, ou seja, já que uma pessoa é considerada socialmente como má, como infratora, o resto de sua família também pode ser classificada da mesma forma. O conceito de estigma, então, não esta relacionado somente ao ex - presidiário, mas aos que o cercam. A fala de uma das egressas ilustra essa dinâmica,

Ah sinto, sinto, é cadeiera, é traficante, foi traficante. Então fica né. Isso aí tem impacto pras pessoas né. Então eu acho que o que eu fiz é uma mancha negra na minha vida. Marco pro resto da minha vida. Acho que até na vida dos meus filhos vai fica essa mancha. Vai fica, uma coisa muito errada que eu fiz, não dá pra esquecer. Nossa se eu pudesse volta atrás eu tomaria outro rumo na minha vida. Marco, e 
na vida da minha filha também por causa dos namorado: ah tua mãe é cadeiera, tua mãe trafico, então fica né. Até pra emprego né das minha filha.

Essa mesma dinâmica é observada nas questões maritais, ou seja, as mulheres de presos podem sofrer discriminação pelo fato de seus companheiros estarem encarcerados, como aponta Guimarães et. al. (2006). Os autores afirmam que essas mulheres são vítimas também de preconceitos que estão relacionados às questões de gênero, uma vez que são obrigadas a se submeter a situações de controle constrangedoras, como a averiguação dos corpos no momento de sua entrada nas prisões para visitas.

Essa situação particular, de acordo com Goffman (1963), pode receber o nome de 'estigma de cortesia', levando o grupo de pessoas que se relacionam com o estigmatizado a receber algumas das privações direcionadas a ele. Ou seja, o conceito de 'estigma de cortesia' exprime a dificuldade que um egresso, no caso desta pesquisa, pode encontrar para construir uma rede de relacionamento, de contatos e apoios que facilite sua reintegração social. Entretanto, o autor afirma que,

Considerei que há um grupo de indivíduos dos quais o estigmatizado pode esperar algum tipo de apoio: aqueles que compartilham seu estigma e, em virtude disso, são definidos e se definem como seus iguais. O segundo conjunto é composto - tomando de empréstimo um termo utilizado pelos homossexuais pelos 'informados', ou seja, os que são normais mas cuja situação especial levou a privar intimamente da vida secreta do indivíduo estigmatizado e a simpatizar com ela, e que gozam, ao mesmo tempo, de uma certa aceitação, uma certa pertinência cortês ao clã. (GOFFMAN, 1963, p. 37)

Podemos observar, no entanto, que mesmo a aceitação dos estigmatizados, ou em nosso caso, dos egressos está relacionada à espacialidade a qual estão vivendo. Observamos um total de $25 \%$ de mulheres egressas que relataram não ter sofrido nenhum tipo de preconceito ou discriminação no momento de sua reintegração social. Esse percentual foi um tanto quanto perturbador, uma vez que pressupúnhamos que essa era uma conseqüência intrínseca ao encarceramento. Quando analisamos mais a fundo essas proposições, chegamos a essa conclusão, ou seja, de que o 'fator' espacial, se assim podemos dizer, é central nessa dinâmica.

Verificamos que o ato de sentir ou não preconceito por parte da vizinhança está relacionada de forma direta ao espaço onde as mulheres têm residência. Desse total, 50\% afirmaram que não sentiram preconceito pelo fato que a vizinhança não sabia de sua condição de ex-presidiária, dificultando assim, a incorporação de qualquer espécie de estigma a sua condição. A restrição espacial dessas mulheres também aparece como motivo de ausência de preconceito, ou seja, o fato de por um período considerável de tempo pós - encarceramento, elas restringirem sua vivência a espacialidade privada, em especial, a doméstica, como representa a fala da egressa apresentada a seguir,

Ah eu nem fiquei, eu vim, não tive dificuldade nenhuma porque eu fui pra casa da minha mãe e ficava lá, não saia mais. Eu ficava só lá dentro com a minha mãe, tomava chimarrão e dormia. Tinha até medo de sair pra fora, medo da policia. Nem ia pra lugar nenhum.

Entretanto, $50 \%$ afirmaram que não sofreram preconceito por residirem em um determinado local. Como apresentamos anteriormente, algumas mulheres que entrevistamos são provenientes de áreas da cidade que são popularmente conhecidas como criminosas, ou até mesmo por nomes como 'cracolância'. Ou seja, estão inseridas em uma espacialidade de alta vulnerabilidade ao ato criminal, na qual a maioria das pessoas já foi encarcerada, sendo, portanto, 'libertadas' do estigma e do preconceito. Cançado (2001, p. 204) nos lembra que "os espaços sociais são demarcados, e o pertencimento a eles deve obedecer a regras de conveniências, não escritas, mas legíveis através dos códigos de comportamento."

Após a experiência carcerária, essas mulheres precisam encontrar maneiras de reestruturar sua vida, superando dificuldades sociais, econômicas e espaciais. Inseridas, por diversas vezes, em 
uma espacialidade de alta vulnerabilidade ao crime, essas mulheres se vêem tentadas a conseguir galgar posições e meios de sobrevivência de forma mais rápida, se envolvendo em muitos casos, novamente, com o mundo criminal. Portanto, é imprescindível que o Estado estimule e crie projetos de apoio a essa população, garantindo a ela uma verdadeira possibilidade de recomeçar suas vidas.

\section{CONSIDERAÇÕES FINAIS}

$\mathrm{Na}$ apresentação de uma de suas obras, Castro, Gomes e Corrêa (1996) nos trazem que a Geografia sempre esteve associada à idéia das explorações. Essas descobertas, anteriormente realizadas principalmente por viajantes e cosmógrafos enfatizavam a aventura de se deparar com o novo, com o desconhecido. A aventura de explorar, de descobrir não cessou, apenas apresentou uma profunda mudança em seu sentido. Os 'novos mundos' da atualidade não são mais representados por terras desconhecidas e locais nunca visitados, mas sim, são extratos do nosso cotidiano, descobertos a partir de novas formas de olharmos, de concebermos e relacionarmos esses aspectos com novos percursos temáticos.

Para os autores, nossas explorações geográficas atuais se remetem diretamente a idéia de repensar antigos processos de conhecimento para assim conceber novos aspectos, novos posicionamentos e novas abordagens. Ou seja, a aventura da descoberta continua, apenas com diferentes pretensões e instrumentos. Novas temáticas em diferentes contextos são exploradas. A questão da criminalidade de mulheres, bem como suas experiências de re-inserção socioespacial após o encarceramento encontra-se nesse hall de novas possibilidades.

Nesse artigo evidenciamos o quanto o espaço tem papel central nessa dinâmica, seja por meio da vivência da espacialidade carcerária, seja facilitando ou dificultando sua re-inserção após a prisão. Utilizamos para construção de nossas ideias, a abordagem acerca do conceito de espaço proposta por Massey (1999), a qual nos leva a pensar um espaço mais plural, dinâmico, aberto, sempre se reconstruindo e desconstruindo mediante a realização de novas conexões, de novas multiplicidades. Não optamos por essa definição por ela ser a única verdadeira, nem ousamos afirmar que ela é a única capaz de conferir inteligibilidade a esse fenômeno, apenas optamos por esta abordagem uma vez que ela nos proporciona uma apreensão mais apropriada a nossos questionamentos. Da mesma forma, ela se constrói a partir de determinados posicionamentos epistemológicos que defendemos em nossa reflexão, ou seja, a necessidade de levarmos em consideração em nossas análises elementos, os quais nem sempre são abordados pela Geografia brasileira, como as especificidades de gênero, classe, sexualidades, raça e etnia, etc.

Por conseguinte, é possível concluir que as discussões desenvolvidas neste artigo estão filiadas às discussões de um sub-campo específico da ciência geográfica. As Geografias Feministas, de base pós-estruturalista, estão "conquistando" um número cada vez maior de pesquisadoras/es, os quais vêm questionando e problematizando temáticas ousadas e inéditas, apontando da mesma forma, que a incorporação de elementos ignorados pela ciência hegemônica e tradicionalista, nos permite o desenvolvimento de reflexões ricas, críticas e pluriversais.

Utilizamos, pois, em nossa argumentação o conceito de gênero, entendido como uma representação, diferenciada temporal e espacialmente, construída mediante a vivência cotidiana dos sujeitos. Essas representações constroem determinados estereótipos culturais, os quais levam a sociedade a esperar certas atitudes de corporalidades específicas. Para compreensão das expressões criminosas de mulheres, essas ideias são valiosas, uma vez que nos auxiliam a entender inúmeras facetas desse fenômeno, tais quais as dificuldades que a sociedade encontra em aceitar essa dinâmica, o constrangimento que determinadas/os pesquisadoras/es encontram para problematizar essas questões, bem como, as especificidades que estão intrinsecamente relacionadas ao mundo criminal feminino, como a maternagem, por exemplo. As discussões acerca do conceito de gênero, já há muito tempo, animam a comunidade geográfica de língua inglesa, mas no Brasil, ainda permanecem periféricas, restritas a pesquisas que ousam desafiar o saber hegemônico. Esse artigo encontra-se nesse escopo. 
Como evidenciamos vários autores vêm se interessando atualmente pelas discussões acerca do processo vivido no período de pós-encarceramento. As proposições permeiam entre noções humanistas de ressocialização e argumentos, talvez mais realistas, de reincidência criminal. O que nos parece mais válido discutir nesse momento é o fato de que as egressas raramente conseguem retomar de forma plena seu cotidiano após o encarceramento, sendo este, encarado como um estigma que as seguirá pelo resto de suas vidas. Da mesma forma, o condicionamento corporal imposto pela espacialidade carcerária permanece em suas ações mais pontuais, como em posições de se sentar ou na opção de abrir ou não as janelas de suas casas.

Suas maiores dificuldades se relacionam ao afastamento sentimental dos filhos, da família e dos companheiros. A estigmatização dessas pessoas pela sociedade também implica em menor probabilidade de conseguirem retomar suas vidas profissionais. O medo do espaço público urbano e o medo de sair de casa também foram relatados pelas egressas, e demonstra o quanto os condicionamentos da espacialidade carcerária são absorvidos. A discriminação ultrapassa a egressa, sendo também, imposta a seus filhos e parentes próximos.

Podemos concluir que, muitas vezes, não são apenas os presos que não estão prontos para voltarem às dinâmicas da vida cotidiana da exterioridade, mas também, que a própria sociedade não está preparada para recebê-los. Rotulando-os e limitando suas chances de re - inserção socioespacial, a população acaba por destruir da mesma forma, suas expectativas e sonhos.

\section{REFERÊNCIAS BIBLIOGRÁFICAS}

ADORNO, Theodor W.; HORKHEIMER, Max. Dialética do esclarecimento; fragmentos filosóficos. Rio de Janeiro: Zahar, 1985.

ARENDT, Hannah. A condição humana. Rio de Janeiro: Forense-Universitária, 1983.

BADINTER, Elisabeth. Rumo Equivocado: o feminismo e alguns destinos. Rio de Janeiro: Civilização Brasileira, 2005.

BARATTA, Alessandro. Resocialización o control social - por um concepto crítico de reintegración social del condenado. In: ARAUJO JUNIOR, João Marcello (Org.). Sistema penal para o terceiro milênio. Rio de Janeiro: Revan, 1991, p. 251-265

BASTOS, Maruza. Cárcere de mulheres. Rio de Janeiro: Diadorim Editora Ltda., 1997.

BITENCOURT, Cezar Roberto. Falência da pena de prisão: causas e alternativas. São Paulo: Saraiva, 2004.

BRASIL, Ministério da Justiça. Sistema Penitenciário Nacional do Brasil. Dados consolidados. Departamento Penitenciário Nacional. Brasília, 2007.

BUTLER, Judith. Problemas de Gênero. Rio de Janeiro: Civilização brasileira, 2003.

BUTLER, Judith. Undoing Gender. New York: Routledge, 2004

CANÇADO, Adriana. Paixão e Honra: Criminalidade Passional em Ponta Grossa na década de 30. In: DITZEL, Carmencita de Holleben M.; SAHR, Cicilian Luiza Lowen. (Org.). Espaço e Cultura. Ponta Grossa: UEPG, 2001.

CARVALHO FILHO, L; F. A Prisão. São Paulo: Publifolha, 2002.

CASTRO, Iná Elias de; GOMES, Paulo Cesar da Costa; CORRÊA, Roberto Lobato. Explorações Geográficas. Rio de Janeiro: Bertrand Brasil, 1996.

CORRÊA, Roberto Lobato. Espaço: um conceito chave da Geografia. In: CASTRO, Iná Elias de; GOMES, Paulo Cesar da Costa; CORRÊA, Roberto Lobato (Orgs.). Geografia: conceitos e temas. Rio de Janeiro: Bertrand Brasil, 1995.

DE JESUS, Damásio. Penas alternativas. São Paulo: Editora Saraiva, 1999

ELIAS, Norbert. Introdução a sociologia. Lisboa: Edições 70, 1970.

FALCONI, Romeu. Sistema presidial: reinserção social? São Paulo: Ícone, 1998.

FIORAVANTE, Karina Eugenia. O espaço carcerário e a reestruturação das relações socioespaciais co- 
tidianas de mulheres infratoras na cidade de Ponta Grossa, Paraná. 2011a. 169 f. Dissertação, Mestrado em Gestão do Território. Universidade Estadual de Ponta Grossa, Ponta Grossa.

FOUCAULT, Michel. Microfísica do poder. Rio de Janeiro: Graal, 1969.

FOUCAULT, Michel. História da sexualidade I: a vontade de saber. Rio de Janeiro: Edições Graal, 1988. FOUCAULT, Michel. Vigiar e Punir. História da violência nas prisões. Petrópolis, RJ: Vozes, 2007.

GELSTHORPE, Loraine. Feminism and criminology. In: MAGUIRE, Mike.; MORGAN, Rod.; REINER, Robert (Orgs.) The Oxford handbook of criminology. Oxford: Oxford University Press, 2002.

GOFFMAN, Erving. Estigma. Notas sobre a manipulação da identidade deteriorada. Rio de Janeiro: Zahar, 1963.

GOFFMAN, Erving. Manicômios, prisões e conventos. São Paulo: Perspectiva, 1988.

GOMES, Paulo Cesar da Costa. A condição urbana: ensaios de geopolítica da cidade. Rio de Janeiro: Bertrand Brasil, 2002.

GOMES, Paulo Cesar da Costa. Um lugar para a Geografia: contra o simples, o banal e o doutrinário. In: MENDONÇA, Francisco de Assis; LOWEN-SAHR, Cicilian Luiza; SILVA, Márcia da. (Orgs) Espaço e Tempo: complexidades e desafios do pensar e do fazer geográfico. Curitiba: Ademadan, 2009.

GUIMARÃES, Cristian Fabiano et al . Homens apenados e mulheres presas: estudo sobre mulheres de presos. Psicologia Social. Porto Alegre, v. 18, n. 3, Dezembro de 2006.

HABERMAS, Jürgen. Mudança estrutural da esfera pública. Rio de Janeiro: Editora

Tempo Brasileiro, 1984.

HARVEY, David. Condição pós - moderna: uma pesquisa sobre as origens da mudança cultural. São Paulo: Edicões Loyola, 1993.

KANTROWITZ, Nathan. Close Control: Managing a Maximum Security Prison - The story of Ragen's Stateville Penitentiary. New York: Harow \& Heaston, 1996.

LEMGRUBER, Julita. Cemitério dos vivos: análise sociológica de uma prisão de mulheres. Rio de Janeiro: Forense, 1983.

LIPOVESTSKY, Gilles. A terceira mulher: permanência e revolução do feminismo. São Paulo: Companhia das Letras, 2000

LYOTARD, Jean François. La condición posmoderna. Madri: Ediciones de Munuir, 1994

MASSEY, Doreen. Spaces of politics. In: MASSEY, Doreen; ALLEN, John; SARRE, Phillip (Orgs.). Human Geography Today. Cambridge: Polity Press, 1999.

MASSEY, Doreen. Pelo Espaço, uma nova política da espacialidade. Rio de Janeiro: Bertrand Brasil, 2008. MCDOWELL, Linda. Doing gender: feminism, feminists and research methods in Human Geography. In: MCDOWELL, Linda; SHARP, Joanne P. Space, Gender, Knowledge. Feminists Readings. London: Arnold, 1997. p. 105-114.

MCDOWELL, Linda; SHARP, Joanne P. Gender, Identity and Place. Understanding Feminist Geographies. Minneapolis: University of Minnesota Press, 1999.

MOLINA, Antonio García-Pablos; GOMES, Luiz Flávio. Criminologia: introdução a seus fundamentos teóricos. São Paulo: Revista dos Tribunais, 1997.

MOURA, Maria Juruena de. Porta fechada, vida dilacerada - mulher, tráfico de drogas e prisão: estudo realizado no presídio feminino do Ceará. Dissertação de Mestrado em Políticas Públicas e Sociedade. 132 f. Universidade Estadual do Ceara, Fortaleza, 2005

OBERHAUSEN, Ann M; RUBINOFF, Donna; DE BRES, Karen; MAINS, Susan; POPE, Cindy. Geographic perspectives on women. In: GALE, Gary L.; WILLMOTT, Cort. J. (Ed.). Geography in America at the dawn of 21st century. Oxford: Oxford University Press, 2003, p. 737-758.

PHILO, Chris. População acumulada: corpos, instituições e espaço. In: AZEVEDO, Ana Francisca; PIMENTA, José Ramiro; SARMENTO, José (Orgs). Geografias do Corpo. Ensaios de Geografia Cultural. Porto: Figueirinhas, 2009.

PIMENTEL, Elaine. Amor bandido: as teias afetivas que envolvem a mulher no tráfico de drogas. Anais do VI Congresso Português de Sociologia, Lisboa, 2008. 
RODRIGUES, Anabela Miranda. Reinserção Social: Uma Definição do Conceito. Revista do Direito Penal e Criminologia, Vol. 34, Rio de Janeiro: Forense, junho/dezembro, 1987.

ROSE, Gillian. Feminism \& Geography. The limits of Geographical Knowledge. Cambridge: Polity Press, 1993.

SANTOS, Milton. A natureza do espaço: Técnica e tempo. Razão e emoção. São Paulo: Editoria da Universidade Estadual de São Paulo, 2008.

SILVA, Joseli Maria. Um ensaio sobre a potencialidade do uso do conceito de gênero na análise geográfica. Revista de História Regional, Ponta Grossa, 2003, 8(1): 31-45, Verão, 2003.

SILVA, Joseli Maria. Análise do Espaço sob a perspectiva de gênero: um desafio para a Geografia Cultural Brasileira. In: ROSENDAHL, Zeny; CORREAA, Roberto Lobato (Orgs.). Geografia: Temas sobre cultura e espaço. Rio de Janeiro: EdUERJ, 2005.

SILVA, Joseli Maria. Amor, paixão e honra como elementos da produção do espaço cotidiano feminino. Espaço e Cultura. Rio de Janeiro, UERJ, n.22, p.97-109, Jan/Dez de 2007.

SILVA, Joseli Maria. Fazendo Geografias: pluriversalidades sobre gênero e sexualidades. In: SILVA, Joseli Maria (Org.) Geografias Subversivas. Discursos sobre espaço, gênero e sexualidade. Ponta Grossa: Todapalavra, 2009.

SOARES, Bárbara Musumeci; ILGENFRITZ, Iara. Prisioneiras: vida e violência atrás das grades. Rio de Janeiro: Garamond, 2002

SOARES, Simone Brandão. Criminalidade Feminina. Revista Democracia Viva. 2006

SOUZA, Marcelo Lopes de. Desafio Metropolitano. Um estudo sobre a problemática sócio-espacial nas metrópoles brasileiras. Rio de Janeiro: Bertrand Brasil, 2000.

VALENTINE, Gill. (Hetero)sexing space: lesbian perceptions and experiences of everyday spaces. Environment and Planning D: Society and space, v. 11,p. 395-413, 1993.

VELHO, Gilberto. Desvio e divergência: uma crítica da patologia social. Rio de Janeiro, Jorge Zahar, 1989. WIESE, Leopold Von. As quatro categorias fundamentais: processo social, distância, espaço social e configuração social. [1933]. Leituras sociológicas. São Paulo: Revista de Sociologia, 1940, v.1, n.1.

Trabalho enviado em janeiro de 2011

Trabalho aceito em junho de 2011 